\title{
Impact of Policy of Government on Import and Export of Sugar from India
}

\author{
Dr. Jyothi, K.C.* \\ DOS in Economics, Kuvempu University, Shankaraghatta - 577 451, Shimoga
}

\begin{abstract}
Sugar is one of the most produced and traded commodities of the world, which has a unique position as one of the most Government regulated commodities in domestic market, but with over 30 percent of world production moving in International trade. Over 110 countries are listed as sugar beet and cane producers. Nearly 60 countries are listed as net exporters. India is the second largest Sugar producing country only after Brazil and is also one among the major sugar exporting countries. India is the world's largest consumer of Sugar at 23.0 million metric tons (MMT) raw value in the 2008-09 marketing year. Human consumption of Sugar in India is up 35 percent from 10 years ago and double the consumption of 20 years ago. In fact in recent years, India has turned out to be a net importer of Sugar, since its domestic production has not been keeping pace with its increasing domestic consumption. Under the structured industrial development policy, Sugar industry was part of the five year plans introduced in 1951 and has been under the direct control of the Government ever since. Sugar industry is highly politicized and closely controlled by the Government.

The Government control covers all aspects of Sugar business, i.e. licensing, capacity, cane area, procurement, cane pricing, sugar pricing, sugar distribution, imports and exports. The Government control varies from full control to partial and hill decontrol which depends upon the local demand. Due to highly politicized and fluctuating policies of the Government, Sugar imports and Exports also vary to a great extent from time to time. This is creating immense problems to the Sugar industries in formulating marketing strategies which in turn have much impact on performance of Sugar industries which ultimately affects the large cane growing farming community of the country.

The present paper discusses the Government policies and their impacts on Sugar import and Export from India. The paper also throws light on the problems faced by the Sugar Industries and Farming community. The necessary steps to be taken for overcoming these problems are also hinted in the paper.
\end{abstract}

\section{Introduction}

India being an agricultural-intensive country, with more than $70 \%$ of the population inhabiting the rural areas, there is a natural feeling in the various governing bodies administering the rural areas, that the more they sustain progress and development in the rural areas particularly in agriculture, through a blend of traditional and modern agricultural practices, the more our country will prosper. It is true.

In the last ten years, India has witnessed a fatigue in the green revolution with the growth rate in food production falling below the population growth. Average size of land holding is also going down with nearly $80 \%$ of the farm families belonging to the marginal and small farmer categories. The cost- risk return structure of farming is becoming unfavorable to farmers due to increasing cost and risk as compared to returns. As a result, indebtedness is growing in rural areas. It is now recognized that, development planning in India has to concentrate to boost agricultural productivity for improving the socio-economic status of rural India. The performance of agriculture can be enhanced by way of irrigation, soil health management, strengthening agriculture technology, post-harvesting technologies, adopting biotechnology, improving in agro-processing technologies, market development and tariffs on imports.

Sugar cane cultivation and development of sugar industry runs parallel to the human civilization and is as old as agriculture. In the present scenario, sugar cane and sugar continue to be important for India's rural economy. Sugar is one of the world's most widely produced and traded commodities. Over 110 countries are listed as sugar beet and cane producers. While, as many countries are listed as net importers and so much so nearly 60 countries are listed as net exporters. Out of the sugar producing countries, many countries are not involved in the final refining and export of crystal sugar. Many of the major sugar producers of Asia and South America like India and Brazil produce and trade in refined sugar.

Sugar industry is highly politicized and closely controlled by the Government. Government control covers all aspects of sugar business i.e. licensing, capacity, cane area, procurement, pricing, distribution, imports and exports. In India sugar seen has been that of protectionism. The mills, farmers and consumers all have been protected one way or another, where as protection to farmers and consumers has been consistent and it has not been so consistent for mill owners. Due to these reasons mill owners are not in a position to decide production and marketing strategies including imports and exports. Mills are not in a position to export sugar when it is 
more profitable. Hence mills are facing severe difficulties and are not able make profits like other sector industries. The present paper discusses the import export details of sugar and the problems faced by the sugar mills in marketing.

\section{History}

India has become second largest producer of sugarcane / sugar producing 155 Million tonnes of sugarcane and 18 million tonnes of Sugar in 2009-10, making it the second largest producer in the world. It has a large consumer base which makes it quite vulnerable to international sugar market, in the event of surplus or deficit situation. At the same time it has good potential and prospectus.

In India sugar production commenced in early 1920's, but it got industry status in late 20's and early 30 's, when India had 29 sugar mills producing just 100,000 MT of sugar. Industry facing competition from imported sugar sought tariff protection. Sugar production picked up under the sugar industry protection act passed in 1932 and country became self sufficient in 1935. After independence Government of India gave prominence for expansion of this sector and thus number of sugar mills increased and there were 138 sugar mills during the first plan period. In the second plan period number of sugar mills increased to 175 with total sugar production of about 31 lakh tonnes. The trend continued and during the ninth plan around 430 sugar mills were in operation with total sugar production of 185 lakh tonnes. During the year 2009-10 number of sugar mills is 488 and the total sugar out put is around 180 lakh tonnes.

\section{International Trade}

India has always been in the international market either for export of import. In last 15 years, India imported 6.596 million tonnes of sugar and exported 4.496 million tonnes of sugar. Imports have outweighed exports. The volume of exports and imports are based on surplus or short fall anticipated or determined between demand and supply.

It is likely due to inconsistent policy, delayed action, monopolization, etc., the imports and exports may have not been most efficiently handled and India may have paid high price for imports and did not get best price for export.

The international trade in India has been highly regulated both in terms of authorization as well as volume. There has been a dramatic change since 1991, with the wave of economic reforms and liberalization policy. Even essential commodities like edible oil and sugar also got freedom / relaxation in imports and exports. While import of sugar was put under OGL, exports got decanalized.

\section{Export Markets}

India has a distinct advantage of its geographical location. It is a land locked with neighboring countries Pakistan, Nepal, Bangladesh. Also Sri Lanka is the nearest country to Southern India. All these countries are regular importers of Sugar. Besides some gulf countries as well as Indonesia have a market for Indian granular sugar. India is most competitive for Pakistan, Bangladesh, Sri Lanka and Nepal. India entered the world market as an exporter in the year 1957 and has exported Sugar all along. The quantity has been as low as 20,000 MT in the year 1984-85 and as high as 4.68 million tonnes in the year 2007-08. The exports have never been an economic proposition due to dual Sugar pricing policy, which makes the free market prices high.

Therefore, to boost the exports Government enforced an Act in 1958, called as Sugar Export Promotion Act. The very purpose of the Act, as the title suggests, was to boost exports. The main features are;

The exports were canalized through two canalizing agencies;

1. State trading corporation of India (STC)

2. Indian Sugar General import Export Corporation (ISGIEC)

These agencies will procure Sugar from the mills willing to supply the sugar, otherwise, as per Act all the mills were obliged to supply for export.

The profit and the loss so achieved on the exports would be shared amongst all the mills on the apportioned quantity.

\section{Imports}

In the last three decades, first import was in 1979-80 and the imports until 1993 were canalized through Government agencies;

- State trading corporation of India

- Food Corporation of India.

The Government under the advice of food ministry would access the shortfall and give directive for import. In 1993-94, anticipating a heavy shortfall of over 2 million tonnes Government allowed free imports under open general license. Almost half of imports were private. Today imports are freely allowed. 


\section{Impact of Decanalization}

How much sugar will be exported-the decision rested with the central Government; i.e. it will announce how much sugar can be exported. The monitoring agency will then issue public notice on the system.

In the long run the policy of Decanalizaion is a non starter, under the dual sugar pricing policy, because domestic price of free sugar is high. International price will determine the economics. The Contribution is negative. The loss will be solely borne by the exporter (earlier it was shared by the entire industry)

\section{Conclusions}

The Indian domestic sugar market is one of the largest markets in the world in volume terms and therefore, the demand for the domestic and not the international market drives sugar promotion in India. Being an essential commodity, the production and marketing of sugar is regulated under the essential commodities act. Therefore the release of sugar for domestic market as well as export is governed by monthly release quotas of the mills.

Since independence, the Government control varied from total control to partial control and total decontrol. Hence the mills are not in a position to decide about marketing strategies. In addition to this the Government planning is also very poor and most of the time has gone by wrong judgments and hence mills have faced much difficulty in marketing. The exports have varied from a small quantity of just 2000 MT to a large quantity of 4.6 lakh tonnes.

Due to improper planning in many situations India has simultaneously imported and exported. The export rates are also not attractive and many times below the domestic price. Hence a long term all friendly sustained Government policy is required in order to boost the performance of sugar mills.

- Greater investment in research and development required for improved seed varieties, adoption of water management practices, improved farm practices are must including better crop management to improve productivity in terms of yield and sucrose content/recovery.

- $\quad$ Conflict between cane prices (SMP \& SAP) need to be sorted out and a consensus needs to be arrived at between the Centre and the States, such that the prices are remunerative for the farmers but not restrictive for the millers. If necessary, the difference between the SMP and SAP can be subsidized by the Government.

- $\quad$ Regulations with respect to sugar exports need to be made less stringent. Exports need to be allowed in situation of sugar surplus and imports of raw sugar allowed in case of deficits to help bridge the supply gap. Incentives and encouragement to be given by the Government to adopt new technologies by the mills to produce refined sugar.

- The monthly release mechanism needs to be removed and levy sugar should be discontinued as $314^{\text {th }}$ of total sugar production in consumed by industrial and business segments and high income households.

- Cyclicality management practices may be put in place. This will provide opportunities to minimize arrears and reducing need for Governmental support.

\section{References}

[1]. Ghosh A.D. (2006). "Sugar Industry-Recent Trends and Outlook", WAR Rating features, p. 36.

[2]. Rama Babu, P. (2008). "The Path Forward", Yojana, pp. 5-6.

[3]. Sharad Joshi (2008). "Sugar Issues", Yojana, pp. 18-19.

[4]. Pandey Adya Prasad (2007). "Indian Sugar Industry- Strong Industrial Base for Rural India”, MPRA, December 2007.

[5]. Satish Kansal (1997). "Factors Determining Indian Sugar Production and its Comparative Advantage", (http://www.fao.org).

[6]. Report of Department of Economic Analysis and Research on Commodity Specific studies on Sugarcane - Uttar Pradesh, Karnataka and Haryana, (http://www.nabard.org). 